\title{
Effect of storage in overcoming seed dormancy of Annona coriacea Mart. seeds
}

\author{
DAIANE M. DRESCH ${ }^{*}$, SILVANA P.Q. SCALON ${ }^{2}$ and TATHIANA E. MASETTO ${ }^{2}$ \\ ${ }^{1}$ Pós-Doutoranda em Agronomia, Universidade Federal da Grande Dourados, (UFGD), \\ Faculdade de Ciências Agrárias, Rodovia Dourados Itahum, Km 12, 79804970 Dourados, MS, Brasil \\ ${ }^{2}$ Universidade Federal da Grande Dourados, (UFGD), Faculdade de Ciências Agrárias, \\ Rodovia Dourados Itahum, Km 12, 79804970 Dourados, MS, Brasil \\ Manuscript received on August 13, 2013; accepted for publication on May 16, 2014
}

\begin{abstract}
The aim of this study was to evaluate the effect of pre-treatments on overcoming dormancy of $A$. coriacea seeds. Seeds were processed and stored in polyethylene bags at temperatures of at $-18^{\circ} \mathrm{C}(42 \% \mathrm{RH}), 5^{\circ} \mathrm{C}$ (34\% RH), $15^{\circ} \mathrm{C}(60 \% \mathrm{RH})$ and $25^{\circ} \mathrm{C}(34 \% \mathrm{RH})$, during 0, 30, 60, 90, 120 and 150 days. After storage, seeds were immersed in $350 \mathrm{mg} . \mathrm{L}^{-1}$ gibberellic acid for 144 hours. Sowing was carried out in plastic bags containing Red Latosol + Bioplant $^{\circledR}$. Moisture content, emergence percentage, emergence speed index, length and dry mass of seedlings, were evaluated. The experimental design was completely randomized in a factorial with four replications of 50 seeds each. The seed storage at $5^{\circ} \mathrm{C}$ and subsequent immersion in gibberellic acid was efficient to reach high percentage, emergence speed and plant growth. A. coriacea seeds showed non-deep simple morphophysiological dormancy wherein the physiological component can be overcome after the seeds are storage at $5^{\circ} \mathrm{C}$ for a maximum period of 53 days and subsequent immersed in exogenous GA (350 mg. $\mathrm{L}^{-1}$ for 144 hours).
\end{abstract}

Key words: Annonaceae, gibberellins, Brazilian Savanna, temperatures.

\section{INTRODUCTION}

The genus Annona (Annonaceae) comprises approximately 250 species in Brazil. Annona coriacea Mart., commonly known as "araticum", "marôlo", "araticum-liso", "araticum-dos-grandes" and "araticum-do-campo" is found in areas of Cerrado (Brazilian savannah) vegetation in the states of Bahia, São Paulo, Minas Gerais, Goiás, Mato Grosso, and Mato Grosso do Sul (Lorenzi 2000, Lorenzi

Correspondence to: Daiane Mugnol Dresch

E-mail: daiamugnol@gmail.com

*(PNPD/CAPES) and Souza 2008). Its leaves are used in popular folk medicine as stomachal, anti-rheumatic and anthelmintic remedies through oral ingestion, as external compresses, by gargling in treating stomatitis, nerve disorders and chronic headaches, and as a cataplasm to treat boils and ulcers by inducing suppuration (Lorenzi and Matos 2002).

Many forest species, including A. coriacea, produce seeds that do not germinate easily even under favorable environmental conditions, indicating the presence of dormancy - which can make seedling production and development under greenhouse 
conditions both expensive and time consuming ( $\mathrm{Da}$ Silva et al. 2007). A number of authors have reported long germination times for seeds of the genus Annona, including Rizzini (1973), who noted that Annona crassiflora Mart. seeds required between 240 and 260 days, while Silva (1998) reported a germination time of 230 - 300 days for the same species, and De Melo et al. (1998) observed a time between 240 - 300 days. These long germination periods can be reduced by applying $\mathrm{GA}_{3}$, as was demonstrated by Pereira et al. (2004) and Cavalcante et al. $(2007,2008)$.

Dormancy is an intrinsic phenomenon among seeds that can provide natural resistance to adverse factors in the environment by impeding germination for a certain period of time even under what might otherwise constitute favorable physical and environmental conditions (of temperature, light/dark, etc) (Bewley and Black 1994, Baskin and Baskin 2004a). Dormancy classification in seeds is based on the permeability of their teguments (or fruits) to water (impermeable or permeable), on embryo morphology (seeds may have underdeveloped or fully-developed embryos), and on numerous physiological responses to temperature (or sequences of temperatures) (Baskin and Baskin 1998, 2004a, b).

Gibberellins such as $\mathrm{GA}_{1}, \mathrm{GA}_{3}, \mathrm{GA}_{4}$ and $\mathrm{GA}_{7}$ are biologically active compounds that can reduce the germination times of dormant seeds, and therefore the time required to produce seedlings. Cold stratification can simulate natural conditions in temperate climates and has been efficiently used as a pretreatment for overcoming dormancy and for promoting germination and seedlings establishment in species whose seeds are dispersed during winter months. Cold stratification can not only increase germination percentages, but also the thermal amplitude under which seeds will germinate (Baskin and Baskin 1998, Chien et al. 2011).

Seed dormancy in some cases manifests itself by means of embryo immaturity (classified as morphological dormancy) when the meristematic tissues of the embryo are not fully differentiated at dispersal. According to Rizzini (1973), when the seeds of $A$. crassiflora are dispersed at the end of the summer their embryos are not yet totally developed and will require a subsequent rest or storage period in order to complete their growth and it is possible that a critical storage period would also be required to overcome dormancy in $A$. coriacea.

Successful seed storage is related to the inherent (or selected) capacity of species to maintain their viability under appropriate environmental conditions; storage under unfavorable conditions, however, will result in precocious germination or deterioration (Schmidt 2007). Many different techniques have been tested to determine the ideal storage conditions for different seeds, and therefore would require involve reducing seed metabolism usually by reducing seed water contents or lowering their storage temperatures (Kohoma et al. 2006). The storage of "orthodox" seeds (such as A. coriaceae) at $-18^{\circ} \mathrm{C}$ has been adopted by most seed banks, and this technique can prolong seed longevity for decades (Chmielarz 2010, Coelho et al. 2012).

A better understanding of the environmental conditions that promote germination is crucial for comprehending the process as well as for commercial considerations, and it is important to obtain information about germination times in the field and at what stage the seeds and the seedlings are best adapted to any given habitat (Baskin and Baskin 1998).

There is currently a significant market for native Cerrado fruits, although most are now harvested only from wild plants using aggressive extractivist and predatory techniques that increase the risk of several species becoming endangered (Aquino et al. 2007).

In light of this situation, more information is needed regarding the methods for overcoming seed dormancy, storage, emergence and increasing the production and establishment of $A$. coriacea seedling. The present work was therefore designed to evaluate the effects of different pretreatments on overcoming the dormancy of $A$. coriacea. seeds. 


\section{MATERIALS AND METHODS}

Fruit COLLECTION AND SEED PROCESSING

Annona coriacea fruits were collected in December/2010 from six mature specimens growing in an area of Cerrado vegetation on the Santa Madalena Farm (22 $2^{\circ} 16^{\prime \prime} \mathrm{S}$ and $\left.55^{\circ} 8^{\prime} 18^{\prime \prime} \mathrm{W}\right)$ in Dourados, state Mato Grosso do Sul (MS), Brazil. The fruit pulp was removed manually and the seeds washed in running water and dried for 12 hours on paper towels in a laboratory environment $\left(25 \pm 1^{\circ} \mathrm{C}\right.$ and $60 \% \mathrm{RH})$. The experiments were undertaken between December/2010 and September/2011 in the Plant Metabolism and Nutrition Laboratory and in an open-air plant nursery (covered by $70 \%$ light reduction screening) at the Agrarian Sciences Faculty of the Grande Dourados Federal University, MS, Brazil.

\section{SEEDS STORAGE AND GERMINATION}

After processing, the loose seeds were stored in polyethylene bags $(0.25 \mathrm{~mm})$ at $-18,5,15$ and $25^{\circ} \mathrm{C}$, during $0,30,60,90,120$ and 150 days. After each storage period, the seeds were sterilized in $3 \%$ sodium hypochlorite for 5 minutes, washed in running water for $3 \mathrm{~min}$, and subsequently immersed in a solution of $350 \mathrm{mg} \mathrm{L}^{-1}$ gibberellic acid $\left(\mathrm{GA}_{3}\right)$ for 144 hours (dose of gibberellic acid and immersion time determined through pre-tests). The seeds were subsequently sown, four centimeters deep into plastic planting sacks containing a mixture of dystrophic red clay Latossol + Bioplant ${ }^{\circledR}$ $(1: 1, v: v)$. Germination and seedling development were accompanied for 120 days after sowing. The Bioplant ${ }^{\circledR}$ substrate was composed of a mixture of bio-stabilized Pinus bark, peat, expanded vermiculite, and coconut fibers corrected for acidity and supplemented with phosphate fertilizer powder $+\mathrm{NPK}+$ micronutrients.

The effects of the different pretreatments on seed germination were evaluated based on following variables: Moisture content - the seeds were dried at $105 \pm 3^{\circ} \mathrm{C}$ for 24 hours, with four replicates of five seeds each, and the results expressed in percentages based on their fresh weights; Emergence Percentage - the evaluations calculated the percentages of emergent seedlings; Emergence Seed Index (ESI) - calculated using the numbers of seedlings that emerged each day divided by the numbers of days between sowing and emergence (Maguire 1962); Lengths of the Aerial and Root Portions - 10 plants were measured (using a millimeter ruler) and the results expressed in $\mathrm{cm}$.seedling ${ }^{-1}$; Numbers of leaves - obtained by counting the total number of leaves per plant; Leaf area: - measured leaf area with an integrator LI-COR Model (LI 3000); Chlorophyll index (SPAD units) - determined using a Konica-Minolta SPAD 502 chlorophyll meter); Dry Mass - obtained in relation to the aerial and root portions of the seedlings, dried to a constant weight at $60^{\circ} \mathrm{C}$ for 72 hours (precision $0.0001 \mathrm{~g}$ ) and expressed as g.seedling ${ }^{-1}$.

The experiments were performed using all possible combinations of temperatures and storage times, with four replicates of 50 seeds each. The results were submitted to analysis of variance and, when significant, the averages at each temperature and each storage time (adjusted using regression equations) were compared using the Tukey test, considering a 5\% level possibility, using the SISVAR software.

\section{RESULTS}

Recently processed seeds of Annona coriacea demonstrated $9.8 \%$ moisture content levels, although when stored at $-18^{\circ} \mathrm{C}$ they demonstrated gradual increases in their moisture contents, reaching $16.01 \%$ humidity by 150 days (Fig. 1). Seeds maintained at $25^{\circ} \mathrm{C}$ did not demonstrate alterations in their moisture contents during storage. Small reductions were noted after 150 days (to $7.3 \%$ and $7.2 \%$ ) among seeds maintained at 5 and $15^{\circ} \mathrm{C}$ respectively. 


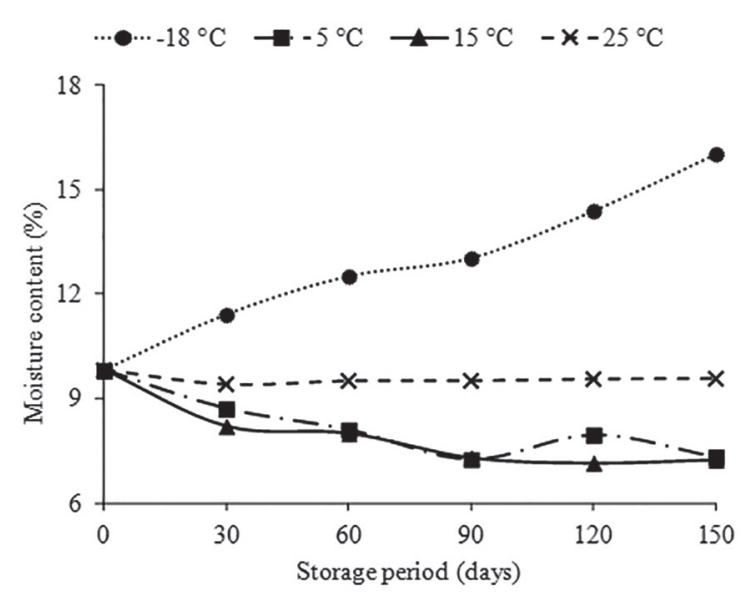

Figure 1 - Seeds moisture content (fresh weight basis \%) of Annona coriacea Mart. after storage at different temperatures and periods.

The seeds that were not stored demonstrated the lowest seedling emergence percentages (44\%), indicating the presence of dormancy in $A$. coriaceae seeds. Based on regression equation, seeds stored for about 53 days at $5^{\circ} \mathrm{C}$ demonstrated the greatest emergence percentages (69.4\%) (Fig. 2A). Storing seeds at low temperatures $\left(5\right.$ and $\left.15^{\circ} \mathrm{C}\right)$ resulted in the greatest emergence velocity indices $(0.6260$ and 0.6141 respectively) (Fig. $2 \mathrm{~B}$ ), with storage at $5^{\circ} \mathrm{C}$ showing the greatest emergence speed (39 days).
Storage at $-18^{\circ} \mathrm{C}$ resulted in the complete loss of viability of $A$. coriacea seeds in terms of all of the characteristics evaluated (Figs. 1, 2, 3, 4 and 5). Both emergence and the emergence speed indices demonstrated reductions after 60 days of storage at 5,15 and $25^{\circ} \mathrm{C}$, with total losses of germination ability after 120 and 150 days (Fig. 2A and B).

In terms of the lengths of the aerial portions of the seedlings, storage at 5 and $25^{\circ} \mathrm{C}$ allowed the greatest growth (9.23 and $9.48 \mathrm{~cm}$, respectively) after the shortest storage times (2.93 and 2.61 days, respectively) (Fig. 3A). In terms of the lengths of the primary roots, storage at 5 and $15^{\circ} \mathrm{C}$ allowed the greatest growth (16.42 and 16.66, cm respectively) after storage for 36 and 38 days respectively (Fig. 3B).

Regarding the number of leaves and leaf area, different storage temperatures and periods negatively affected leaf growth of seedlings (Figure 4A and B). For chlorophyll indexes quadratic adjustments in all storage temperatures, were observed and the highest indexes estimated at temperatures of 5,15 and $25^{\circ} \mathrm{C}$ (41.15, 38.37 and 41.26 SPAD units, respectively) after 1, 28 and 15 days of storage, respectively. However, positive effect of storage at $5^{\circ} \mathrm{C}$ were observed, such as the measurements of the dry masses of the
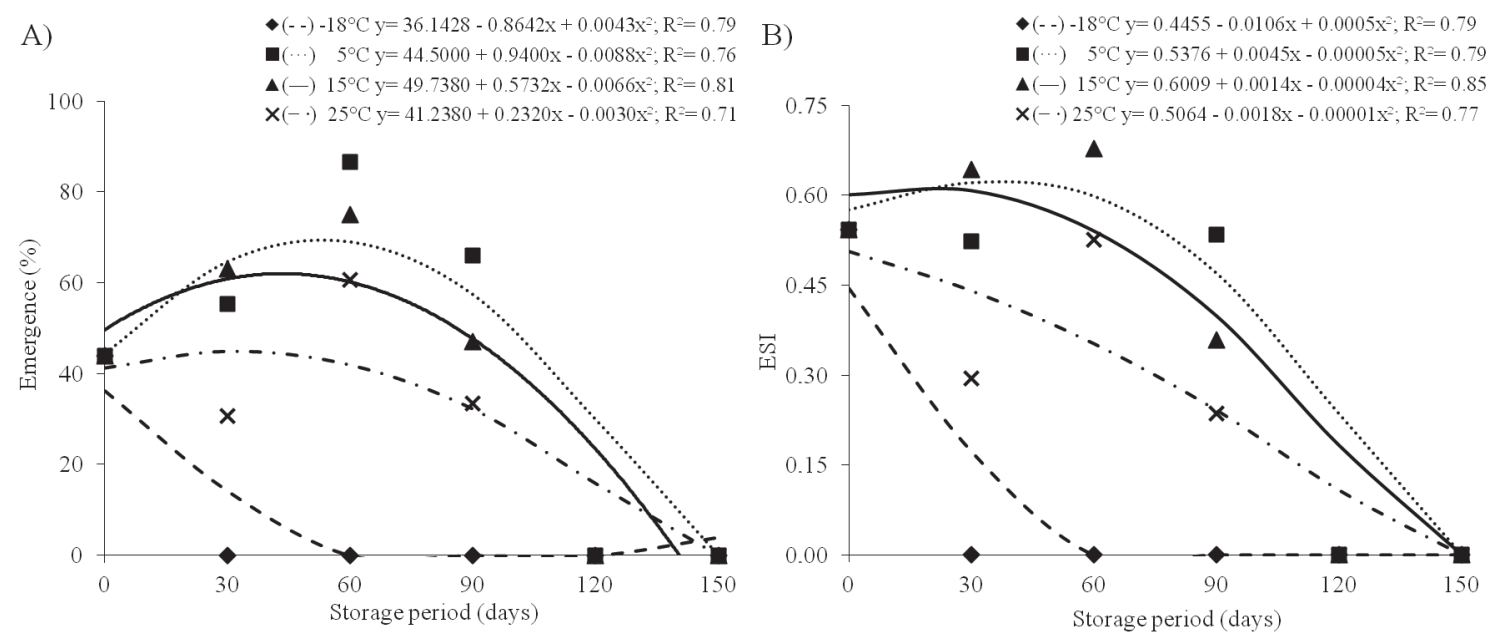

Figure 2 - Percentage emergence (\%) (A) and emergence speed index (ESI) (B) of Annona coriacea Mart. after storage at different temperatures and periods. 

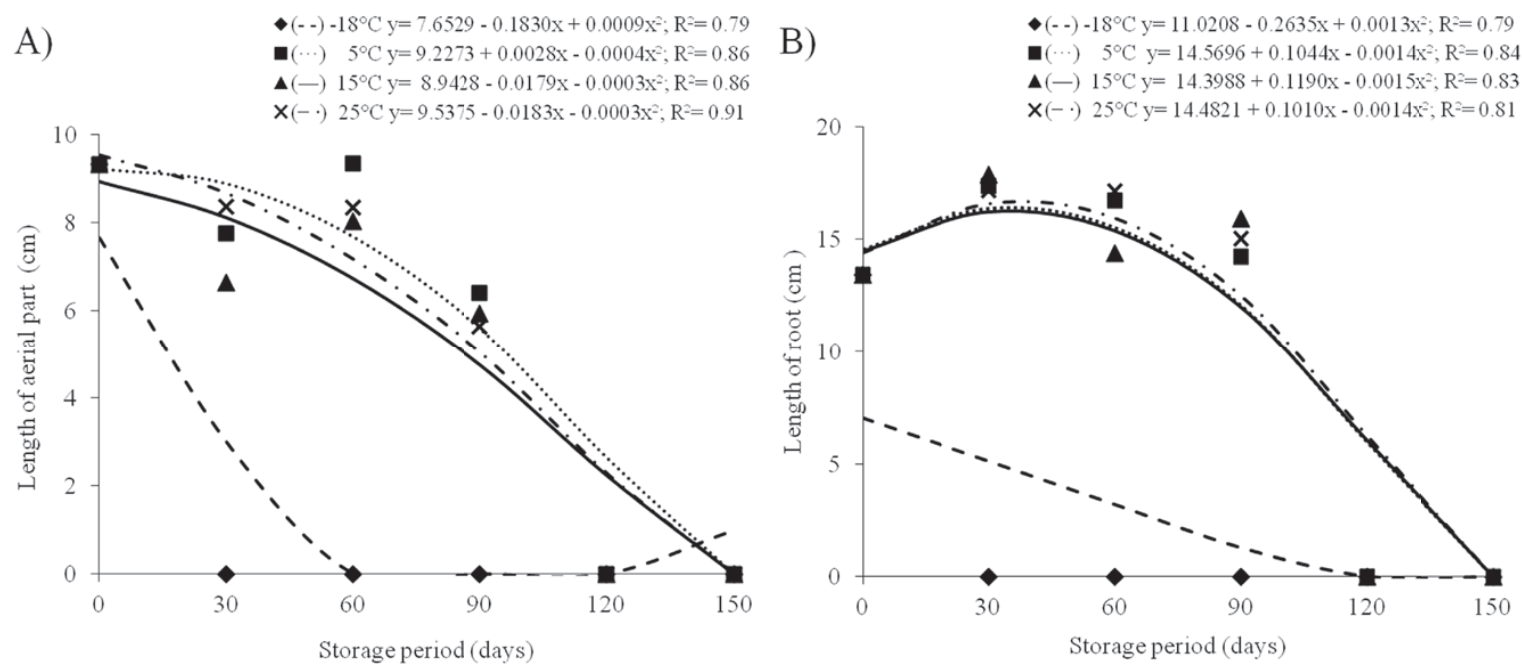

Figure 3 - Length of aerial part (cm seedlings $\left.{ }^{-1}\right)$ (A) and length of root (cm seedlings $\left.{ }^{-1}\right)(\mathrm{B})$ of Annona coriacea Mart. after storage at different temperatures and periods.
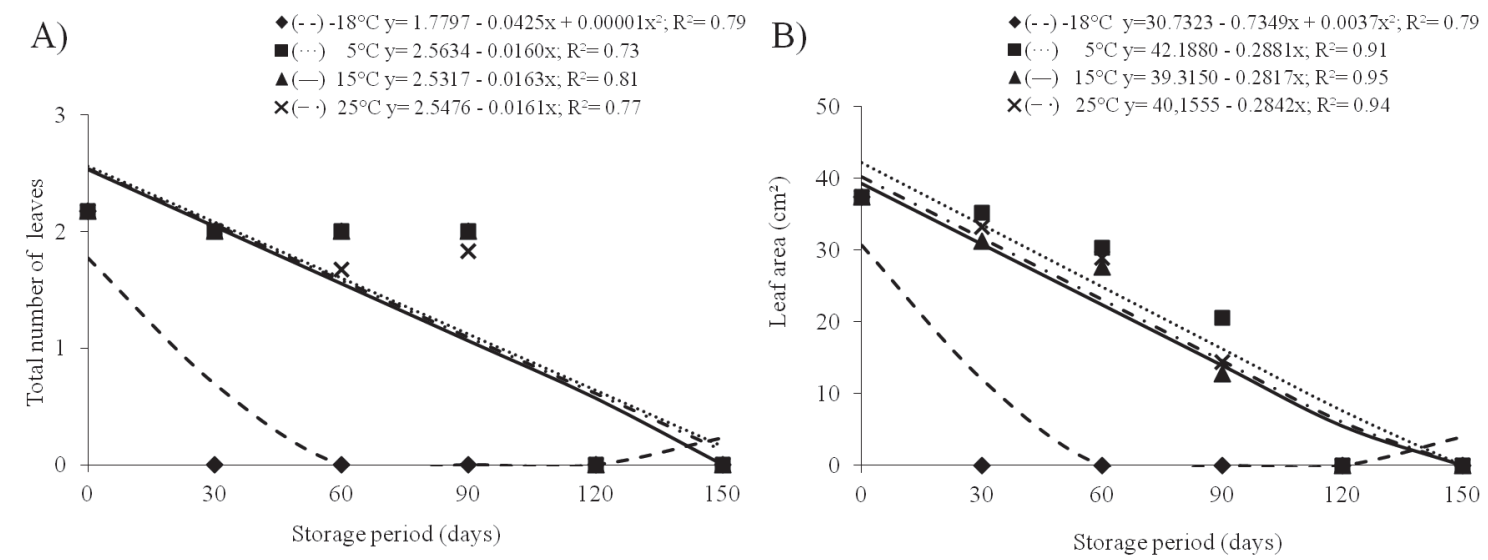

C)

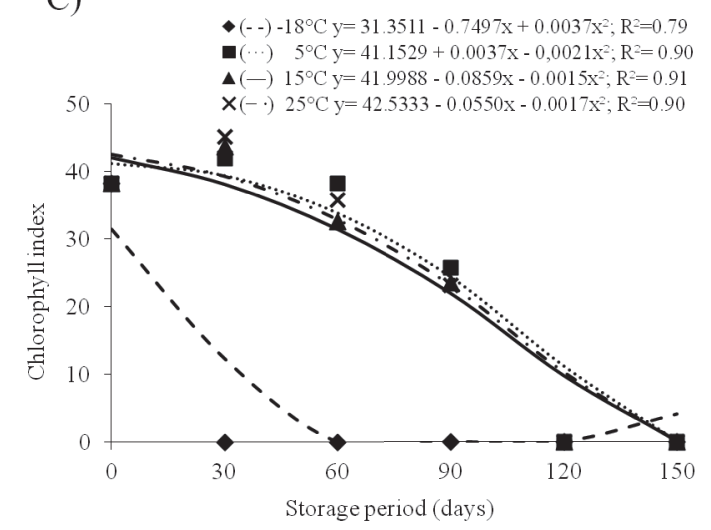

Figure 4 - Numbers of leaves (A), leaf area (B) and chlorophyll index (SPAD units) (C) of Anona coriacea Mart. after storage at different temperatures and periods. 
aerial portions $(0.1494 \mathrm{~g})$ and the roots $(0.6402 \mathrm{~g})$ as estimates by the regression equation after 35 and 3 days of storage, respectively (Fig. 5A and B). Seeds stored at $15^{\circ} \mathrm{C}$ and $25^{\circ} \mathrm{C}$ demonstrated smaller seedlings and, consequently, smaller dry mass accumulations in their aerial and root portions (Fig. 5A and B).

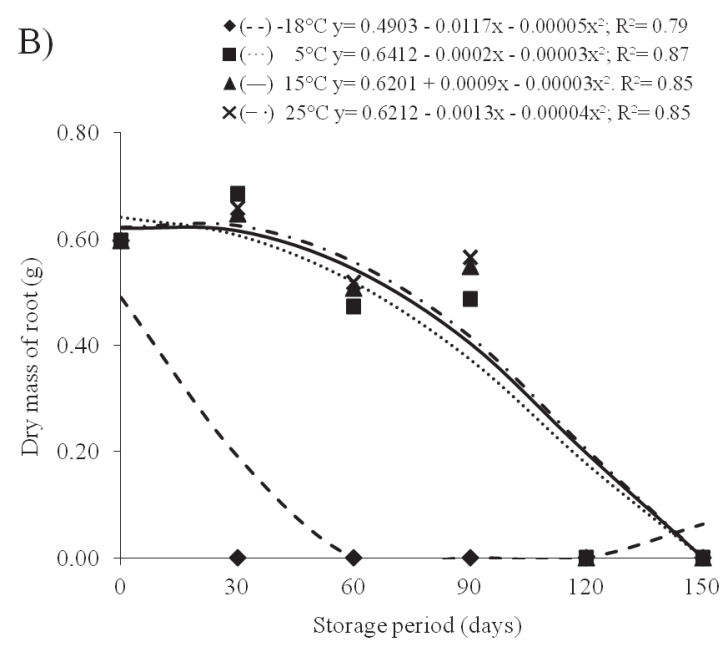

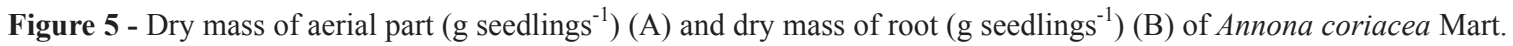
after storage at different temperatures and periods.

\section{DISCUSSION}

The increases in the moisture content of Annona coriacea seeds observed after storage at $-18^{\circ} \mathrm{C}$ may have been associated with the formation of ice crystals. In any way, the high germination percentages and germination velocity indices of seeds stored at $5^{\circ} \mathrm{C}$ indicated that this low storage temperature, with the subsequent addition of gibberellic acid, was sufficient to overcome seed dormancy in A. coriaceae, indicating the breaking of physiological dormancy by temperature reductions. According to the seed dormancy classification system proposed by Baskin and Baskin (2004a), the type of dormancy of $A$. coriacea seeds can be considered morphophysiological (MPD). Seeds demonstrating this type of dormancy have poorly developed embryos as the physiological component of dormancy, requiring a pretreatment to overcome dormancy before germination can proceed.

Seeds demonstrating MPD require considerably longer periods of time for embryo growth/ root emergence than the seeds demonstrating morphological dormancy (Baskin and Baskin 2004a). According to the protocol proposed by Baskin and Baskin (1998) and Walck et al. (1999), eight levels of morpho-physiological dormancy can be identified based on the effects of combined (or not) treatments of hot/cold temperatures and the addition (or not) of $\mathrm{GA}_{3}$.

According to our results, A. coriacea seeds demonstrated simple, non-profound, morphophysiological dormancy as dormancy was overcome by storing them at $5^{\circ} \mathrm{C}$ (for 53 days), by the posterior addition of gibberellin, and by embryo growth at higher temperatures during their presence in the greenhouse $\left(25 \pm 3^{\circ} \mathrm{C}\right)$. According to Chien et al. (2011), simple, non-profound, morpho-physiological dormancy can be broken by stratification (either hot or cold), depending on the species, although the best embryo growth occurs at higher temperatures than those favorable to cold stratification (Baskin and Baskin 1998). The requirement for environmental temperatures above zero for cotyledon emergence 
represents an adaptation for awarding seedling lesions during rigorous winters (Masuda and Washitani 1990).

Similar results were reported by Baskin and Baskin (1998) and Da Silva et al. (2007), who identified the dormancy of $A$. crassiflora as being of the simple, non-profound, morpho-physiological type, with dormancy being overcome only by the combined effects of cold stratification and the application of $\mathrm{GA}_{3}$.

Chien et al. (2011) observed that Ilex maximowicziana Loes. seeds had germination levels above $90 \%$ when incubated at $25^{\circ} \mathrm{C}, 20 / 10^{\circ} \mathrm{C}$, or $25 / 15^{\circ} \mathrm{C}$, and did not require cold stratification to break dormancy thus demonstrating simple, non-profound, morpho-physiological dormancy. Martins et al. (2012) reported that Picconia azorica (Tutin) Knobl. seeds demonstrated germination and embryonic characteristics typical of simple, non-profound, morpho-physiological dormancy, as well as the occurrence of a possible chemical inhibition mechanism. These authors also reported that epicotyl development required low temperatures, and that up to three months were needed for cotyledon leaf expansion, and they recommended incubating seed without coating at a temperature of $10 / 5^{\circ} \mathrm{C}$ or $15 / 10^{\circ} \mathrm{C}$.

It is important to note that $A$. coriacea seeds are dispersed under high temperature conditions (summer) in the natural environment in Cerrado vegetation and are subsequently exposed to a low temperature period (fall/winter) which breaks physiological dormancy through that thermal transition (warm/cold); as a result, root protrusion and seedling emergence occur only in the Spring when temperatures are more suitable. Da Silva et al. (2007) reported that the physiological component of the morpho-physiological dormancy of Annona. crassiflora Mart. seeds is broken by low temperatures and/or the temperature fluctuations that precede the rainy season (October), and by the application of exogenous GA.

In terms of $A$. coriacea seeds, storage at $5^{\circ} \mathrm{C}$ followed by the application of gibberellic acid
$\left(\mathrm{GA}_{3}\right)$ for 144 hours overcome seed dormancy, with the highest emergence rate $(69.4 \%)$ estimated by the regression equation after 53 days of storage. A. crassiflora seeds that were stored for 180 days required 59 days to emerge (approximately 25\% emergence) after immersion in a $4000 \mathrm{mg} \mathrm{L}^{-1}$ gibberellic acid solution for 73 hours (Cavalcante et al. 2007). According to Baskin and Baskin (2004a), the quantities of GA necessary to initiate the germination of mature seeds is controlled by their exposure to different abscisic acid concentrations during seed development, where seeds exposed to low levels of abscisic acid during development ("low-level dormancy"), require only low levels of GA to germinate, while seeds exposed to high concentrations of abscisic acid during development ("profound dormancy") require high GA concentrations to germinate. Our results showed that the use of $350 \mathrm{mg} \mathrm{L}^{-1}$ of gibberellic acid $\left(\mathrm{GA}_{3}\right)$ for an extended period of time (144 hours) was able to improve $A$. coriacea seedlings production under plant nursery conditions. These pretreatments resulted in the high emergence percentages (69.4\%) required for commercial nursery activities, which aim for rapid seedling emergence, with low energy and resource consumption, and high emergence totals.

The viability losses observed in seeds stored at $-18^{\circ} \mathrm{C}$ were probably the result of the formation of ice crystals in the cell interiors, indicating intolerance to freezing. Low emergence percentages and emergence velocities of seedlings after 60 days of storage indicated there was deterioration. Similar results in terms of the percentages and velocities of emergence were seen in measurements of the growth and development of the aerial, root portions of the seedlings and chlorophyll index after 60 days of storage, regardless of their storage temperatures. This behavior reflected seed deterioration during storage, which probably negatively impacted reserve translocation and therefore the formation of those expanding plant structures, as observed in the lower leaf growth of seedlings through variable number of leaves and leaf 
area. According to Terskikh et al. (2008), among the main processes observed during seed deterioration are the exhaustion and chemical alteration of embryo reserves (including lipid oxidation and partial degradation of proteins), alterations of cell membrane properties (their reduced integrity and organization, and increases in permeability), and enzymatic and nucleotide alterations.

The seed storage temperature of $5^{\circ} \mathrm{C}$ contributed to the higher accumulation of biomass in the aerial part and roots. According to Haase (2008), seedlings that demonstrated high root biomasses tended to grow more and show better survival rates than seedlings with smaller root biomasses with strict correlations between the dry masses of the roots and the heights of the aerial portions.

Storing A. coriacea seeds at $5^{\circ} \mathrm{C}$ and their subsequent immersion in gibberellic acid (350 mg L $\mathrm{m}^{-1}$ for 144 hours) was sufficient for obtaining high germination percentages and high seedling emergence and growth velocities. A. coriacea Mart. seeds demonstrated simple, non-profound, morpho-physiological dormancy that could be overcome by storage at $5^{\circ} \mathrm{C}$ for no more than 53 days and the subsequent immersed in exogenous GA.

\section{RESUMO}

O objetivo desse trabalho foi avaliar o efeito dos prétratamentos na superação de dormência de sementes de Annona coriaceae. As sementes foram processadas e armazenadas em embalagens de polietileno nas temperaturas de $-18^{\circ} \mathrm{C}\left(42 \%\right.$ UR), $5^{\circ} \mathrm{C}$ ( $34 \%$ UR), $15^{\circ} \mathrm{C}\left(60 \%\right.$ UR) e $25^{\circ} \mathrm{C}(34 \%$ UR), durante $0,30,60$, 90, 120 e 150 dias. Após o armazenamento, as sementes foram imersas em $350 \mathrm{mg} . \mathrm{L}^{-1}$ de ácido giberélico por 144 horas. A semeadura foi realizada em sacos plásticos contendo Latossolo Vermelho + Bioplant $^{\circledR}$. O teor de água, porcentagem de emergência, índice de velocidade de emergência,comprimentosemassasecadas plântulasforam avaliados. O delineamento foi inteiramente casualizado em esquema fatorial com quatro repetições de 50 sementes.
Para as sementes de $A$. coriacea, o armazenamento das sementes a $5^{\circ} \mathrm{C}$ e posterior imersão em ácido giberélico é eficiente para obter elevada porcentagem, velocidade de emergência e crescimento de plantas. As sementes de A. coriacea apresentam dormência morfofisiológica nãoprofunda simples, sendo que componente fisiológico pode ser superado com o armazenamento a $5^{\circ} \mathrm{C}$ por um período máximo de 53 dias e posterior imersão em GA exógeno (350 mg. $L^{-1}$ por 144 horas).

Palavras-chaves: Annonaceae, giberelina, Cerrado, temperaturas.

\section{REFERENCES}

Aquino FG, Walter BMT AND RiBEIRo JF. 2007. Woody community dynamics in two fragments of "cerrado" stricto sensu over a seven-year period (1995-2002), MA, Brazil. Rev Bras Bot 30: 113-121.

BASKIN CCAND BASKIN JM. 1998. Seeds: ecology, biogeography, and evolution of dormancy and germination. San Diego: Academic Press.

BASKIN CC AND BASKIN JM. 2004b. Determining dormancybreaking and germination requirements from the fewest seeds. In: Guerrant E, Havens K and Maunder M (Eds), Ex situ plant conservation: supporting species survival in the wild. Covelo, CA, Island Press, p. 162-179.

BASKIN JM AND BASKIN CC. 2004a. A classification system for seed dormancy. Seed Sci Res 14: 1-16.

BEWLEY JD AND BLACK M. 1994. Seeds: physiology of development and germination. $2^{\text {nd }}$ ed., New York: Plenum, 445 p.

CaVAlcante TRM, Naves RV, Braga Filho JR And Silva LB. 2007. Influência de substratos e do armazenamento de sementes sobre a emergência e crescimento de plântulas de araticum (Annonaceae). Biosc J 23: 11-20.

CAVAlCante TRM, NAVES RV, SERAPHIN JC AND CARVAlHo GD. 2008. Diferentes ambientes e substratos na formação de mudas de araticum. Rev Bras Frutic 30: 235-240.

CHIEN C, CHEN S, CHIEN T, BASKIN JM AND BASKIN CC. 2011. Nondeep simple morphophysiological dormancy in seeds of Ilex maximowicziana from northern (subtropical) and southern (tropical) Taiwan. Ecol Res 26: 163-171.

ChMielarz P. 2010. Cryopreservation of conditionally dormant orthodox seeds of Betula pendula. Acta Physiol Plant 32: 591-596.

Coelho N, Gonçalves S, GonzÁlez-Benito ME AND ROMANO A. 2012. Germination and cryopreservation tolerance of seeds from the rare aromatic species Thymus lotocephalus. Sci Hort 145: 84-86.

Da Silva EAA, Melo DlB, Davide AC, Bode N, Abreu GB, FARIA JMR AND HILHORST HW. 2007. Germination Ecophy-siology of Annona crassiflora Seeds. Ann Bot 99: 823-830. 
De Melo JT, Da Silva JA, De Torres RAA, Silveira CE AND CALDAS LS. 1998. Coleta, propagação e desenvolvimento inicial de espécies do cerrado. In: SANO SM AND AlmeIDA SP (Eds), p. 193-243. Cerrado: ambiente e flora. Planaltina: Embrapa-CPAC.

HAASE D. 2008. Understanding forest seedling quality: measurements and interpretation. Tree Planter's Notes. United States: Department of Agriculture/ Forest Service 52: 24-30.

Kohoma S, Maluf AM, Bilia DAC And Barbedo CJ. 2006. Secagem e Armazenamento de sementes de Eugenia brasiliensis Lam. (Grumixameira). Rev Bras de Sementes 28: $72-78$

LORENZI H. 2000. Árvores Brasileiras-Manual de Identificação e Cultivo de Plantas Arbóreas Nativas do Brasil. v.1. $3^{\mathrm{a}}$ ed., Editora Plantarum. Nova Odessa, SP, 368 p.

Lorenzi H AND Matos FJA. 2002. Plantas medicinais no Brasil: nativas e exóticas, p. 62-63. (Instituto Plantarum, ed.), Nova Odessa.

LORENZI H AND SOUZA VC. 2008. Botânica sistemática: Guia ilustrado para identificação das famílias de Fanerógamas nativas e exóticas no Brasil, baseado em APG II. $2^{\text {a }}$ ed., Instituto Plantarum, Nova Odessa, Brasil, 703 p.

MAGUIRE JD. 1962. Speed of germination aid in selection and evaluation for seedling emergence and vigor. Crop Scie 2: $176-177$.
MARTINS JM, MOREIRA OCB, RAINHA NFP, BAPTISTA JAB, SILVA L AND MoURA MMT. 2012. Morphophysiological dormancy and germination in seeds of the Azorean tree Picconia azorica. Seed Sci and Technol 40: 163-176.

MASUDA M AND WASHITANI I. 1990. A comparative ecology of the seasonal schedules for reproduction by seeds in a moist tall grassland community. Funct Ecology 4: 169-182.

Pereira EBC, Pereira AV, Melo JT, Sousa-Silva JC AND FALEIRO FG. 2004. Quebra da dormência de sementes de araticum. Planaltina: Embrapa Cerrados, 15 p. (Boletim de pesquisa e desenvolvimento, 137).

RizZINI CT. 1973. Dormancy in seeds of Annona crassiflora Mart. J Exp Bot 24: 117-123.

SCHMIDT L. 2007. Tropical forest seed. New York: Springer, 409 p.

SILVA JA. 1998. Coleta e produção de mudas de frutas nativas do cerrado. Planaltina: Embrapa - CPAC, 2 p. (Guia técnico do produtor rural, 15).

TERSKiKh VV, ZENG YJ, FeURTAdo A, Giblin M, ABrams SR AND KERMODE AR. 2008. Deterioration of western redcedar (Thuja plicata Donn ex D. Don) seeds: protein oxidation and in vivo NMR monitoring of storage oils. J Exp Bot 59: 765-777.

WALCK JL, BASKIN CC AND BASKIN JM. 1999. Seeds of Thalictrum mirabile (Ranunculaceae) require cold stratification for loss of nondeep simple morphophysiological dormancy. Can J Bot 77: 1769-1776. 
